\title{
High revolution chemical motor with biocatalytic reaction
}

\section{生体触媒を用いた高回転型ケミカルモーターに関する研究}

\author{
Yuki MATSUURA \\ Graduate School of Medical and Dental Sciences, Tokyo Medical and Dental University \\ 2-3-10 Kanda-Surugadai, Chiyoda-ku, Tokyo 101-0062, Japan
}
Masaharu KOZUKA, Munkhjargal MUNKHBAYAR, Yuta SATO, Daishi TAKAHASHI, Takahiro ARAKAWA, Hiroyuki KUDO and Kohji MITSUBAYASHI Institute of Biomaterials and Bioengineering, Tokyo Medical and Dental University Kanda-Surugadai, Chiyoda-ku, Tokyo 101-0062, Japan
TEL: x81-3-5280-8091 FAX: x81-3-5280-8094 e-mail: m.bdi@tmd.ac.jp
( Received 10, Febrary 2010 Accepted 14, April 2010)

\begin{abstract}
A chemical motor was constructed by a catalase immobilized tube-pump and a micro turbine system was developed and demonstrated. The catalase tube-pump produced an active pressure of oxygen vapor at the tube-inside by applying hydrogen peroxide to the tube-outside as chemical energy, resulting in the oxygen gas flux. The micro bladed wheel of the artificial turbine was revolved by the oxygen flux from the tube-pump, thus the rotational velocity was correlated with the $\mathrm{H}_{2} \mathrm{O}_{2}$ concentration. The potential applications of the chemical motor will allow to develop some intelligent biomimetic machines.
\end{abstract}

Keywords : Chemical motor, Micro turbine system, Enzymatic reaction, Hydrogen peroxide

\section{INTRODUCTION}

生体内や生物には、モータータンパク質による筋肉の 収縮・弛緩の動きや真正細菌の鞭毛を動かしている鞭毛 モーターなどの様な高性能な運動機構が存在している。 細胞内には化学エネルギーを機械的な動きに変換する分 子モーターと呼ばれるものがある。この分子モーターの 働きによって、細胞は変形・移動することが出来、細胞 内では様々な高分子の輸送が行われている。鞭毛モータ 一は、化学エネルギーを機械エネルギーへと直接変換し ており、人工的な運動機構と比較して非常に高いエネル ギー変換効率を有している。このエネルギー変換機構を 模倣・利用することで、優れた運動機構を構築できるも のと考えられる。我々はこれまでに、酵素を用いた能動 的な圧力発生システムを構築してきた。このシステムは 生体触媒であるカタラーゼを用い、触媒反応にて生成さ れる $\mathrm{O}_{2}$ のガス化にて圧力を発生するものである。本研究 では、生体由来の酵素であるカタラーゼを用いて $\mathrm{H}_{2} \mathrm{O}_{2}$

SAS Award was given to this paper presented as Poster Presentation at the 2009 SAS Intelligent Symposium.
にて駆動するケミカルモーター用ポンプを作製し、その ポンプ上部にタービンを取り付けることで、化学エネル ギーによって駆動するケミカルモーターを構築した。

\section{EXPERIMENTAL SECTION}

酵素タンパク質は、高い基質特異性を有し、生体内に おいて様々な化学反応を触媒する作用が知られ、基質と の触媒反応に伴い熱、光、化学物質の濃度変化等が発生 することから、現在はバイオセンサの材料として用いら れている。本研究で利用したカタラーゼ (catalase, EC 1.11.1.6）は酵素の中でも非常に高い触媒活性を有し、下 式に示すように、 $\mathrm{H}_{2} \mathrm{O}_{2}$ を基質とし、触媒反応に伴い多量 の酸素と水を生成する。

$$
2 \mathrm{H}_{2} \mathrm{O} \stackrel{\text { catalase }}{\longrightarrow} \mathrm{O}_{2}+2 \mathrm{H}_{2} \mathrm{O}
$$

この触媒反応を用いたチューブ型ポンプの構造とその 評価系を Fig. 1 に示す。能動圧力発生デバイスの圧力発 生部分にはカタラーゼ固定化チューブを用いた。ケミカ ルモーター用ポンプの作製ではまず、カタラーゼと光架 
橋性樹脂の混合液を透析チューブの内表面に塗布し、冷 蔵暗所にて 1 時間乾燥させた後、2 時間の紫外線照射に より包括固定化することで、酵素固定化チューブとした。 次にチューブの一端を閉塞させ、リン酸緩衝液を注入し ケミカルモーター用ポンプとした。

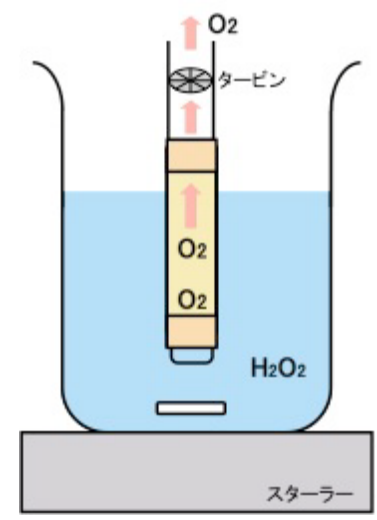

Fig.1. Schematic diagram for a chemical motor with enzymatic reaction

特性評価では、ケミカルポンプを $\mathrm{H}_{2} \mathrm{O}_{2}$ に浸漬し、ポ ンプ内からの酸素吐出流量を測定した。タービンの作製 ではまず、PET シートからファンの平面パターンを切り 出し、シャフトと軸受を取り付けることでタービンとし た。最後にケミカルポンプとタービンを組み合わせたケ ミカルモーターを構築し、回転の様子をカメラで動画撮 影することで $\mathrm{H}_{2} \mathrm{O}_{2}$ 濃度に対するケミカルモーターの回 転特性を評価した。

\section{RESULTS AND DISCUSSION}

$\mathrm{H}_{2} \mathrm{O}_{2}$ 溶液の滴下に伴い、カタラーゼ固定化チューブ内 部において触媒反応に伴う酸素の生成が観察された。こ れはビーカー内の $\mathrm{H}_{2} \mathrm{O}_{2}$ 溶液がチューブを透過して、カ タラーゼ固定化面で多量の酸素が発生し、チューブ内の 体積増加を導いたと考えられる。ケミカルモーター用ポ ンプの評価として、 $\mathrm{H}_{2} \mathrm{O}_{2}$ 濃度 $93.44 \mathrm{mmol} / \mathrm{l}$ にて酸素吐出 流量を計測したところ流量の増加が確認された（Fig. 2)。 また、作製したケミカルポンプは、計測後にリン酸緩衝 液にて洗浄することで、再現性よく酸素を生成すること ができ、連続的な使用が可能であることが確認された。

次に、ケミカルモータ用のタービンを $\mathrm{CO}_{2}$ レーザマー カを用いて作製した。作製したタービンの回転数はエア チャージャーの流速に高い相関を示した。これらの要素 を組み合わせたケミカルモーターを $\mathrm{H}_{2} \mathrm{O}_{2}$ に浸漬させる と、カタラーゼの触媒反応に伴う圧力増加によりファン の回転が観察された。ハイスピードカメラでの撮影画像
よりタービンの回転数を求め、 $\mathrm{H}_{2} \mathrm{O}_{2}$ 濃度と回転数に高い 相関が確認された。各 $\mathrm{H}_{2} \mathrm{O}_{2}$ 濃度に応じた回転数の上昇 が確認された。2 mol/l $の \mathrm{H}_{2} \mathrm{O}_{2}$ 溶液に対し、約 $1000 \mathrm{rpm}$ の回転速度でタービンの回転が確認された。以上の結果 から、電力や機械を必要としない、化学エネルギーにて駆動 し、回転数を制御できる人工化学モーターを構築した。

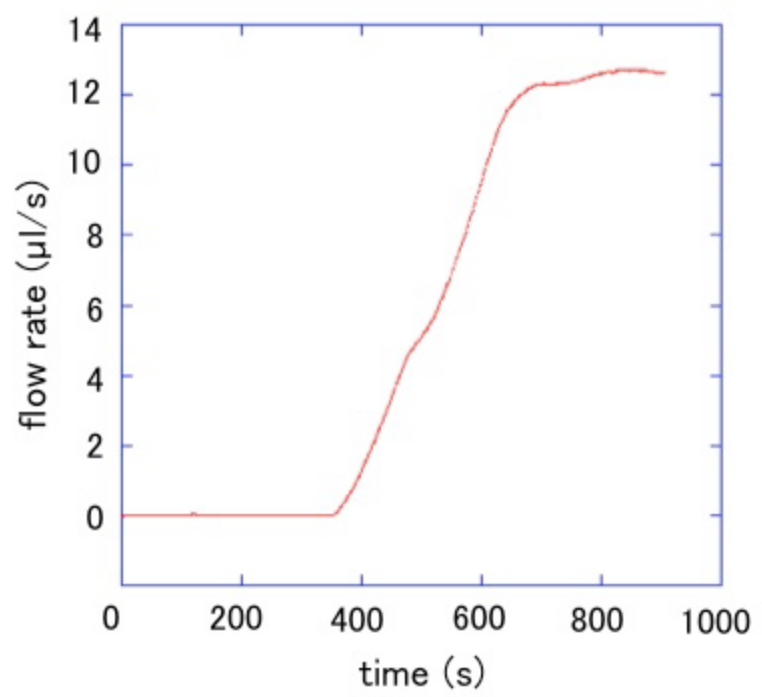

Fig.2. Typical responses of flow rate of the chemical motor to $\mathrm{H}_{2} \mathrm{O}_{2}$ concentration of $93.44 \mathrm{mmol} / \mathrm{l}$.

\section{CONCLUSION}

生体認識材料である酵素を用い、 $\mathrm{H}_{2} \mathrm{O}_{2}$ の化学エネルギ 一を直接動力源とする新しい人工化学モーターを開発し た。生体由来の酵素であるカタラーゼを用いて $\mathrm{H}_{2} \mathrm{O}_{2}$ に て駆動するケミカルモーター用ポンプを作製し、そのポ ンプ上部にタービンを取り付けることで、化学エネルギ 一によって駆動するケミカルモーターを構築した。

\section{ACKNOWLEDGEMENTS}

本稿にて紹介した研究の一部は、文部科学省特別教育 研究経費「センシングバイオロジーにおける基盤技術の 戦略的推進事業」、及び、日本学術振興会科学研究費補助 金の助成による。

\section{REFERENCES}

${ }^{1}$ K. Mitsubayashi, T. Ohgoshi, T. Okamoto, Y. Wakabayashi, M. Kozuka, K. Miyajima, H. Saito, H. Kudo, Biosens. Bioelectron., 24, 1518(2009).

${ }^{2}$ T. T. Sand, J. E. Zielinski, C. Arthur, D. Bradley, S. Wie, Biosens. Bioelectron. 18, 797(2003). 